Относительное количество CD56+ (\%) в общей группе с ЖДА $12.5 \pm 2.14 \%$, а в контрольной группе $31.7 \% \pm 2.27 \%$. Это говорит об ослаблении цитолитической активности клеток CD56+. Разница в статистической точности для всех групп ЖДА клеток CD56+ составила $\mathrm{p}<0,05$ по сравнению с контрольной группой. Была получена средняя сила связи коэффициента корреляции клеток CD56+ с гемоглобином и сывороточным железом в общей группе ЖДА $\mathrm{r}=0.43$ и $\mathrm{r}=0.32$ соответственно.

\title{
Заключение:
}

Таким образом, для детей с ЖДА наблюдалась типичная картина:

- По мере увеличения тяжести ЖДА у детей наблюдалось значительное ослабление клеточного компонента приобретенного иммунитета (CD3, CD4, CD8). Высокая положительная корреляция сывороточного железа с относительным количеством клеток CD3 и CD4 в общей группе с ЖДА $(\mathrm{r}=0,8)$ показала, что дефицит железа играет важную роль при ослаблении клеточного иммунитета.

- Дефицит также наблюдался в других естественных клетках-киллерах CD56, которые являются индикаторами врожденного иммунитета. Результаты могут быть оценены как нарушение иммунного баланса, связанное с дефицитом клеточного иммунитета у детей с ЖДА.

1. World Health Organization. Nutritional anaemias: tools for effective prevention and control. Geneva: World Health Organization. - 2017.

2. Kehl-Fie, TE, Skaar, EP. Nutritional immunity beyond iron: a role for manganese and zinc. Curr Opin Chem Biol. 2010; 14:218-224.

3. Eugene D Weinberg. Iron Availability and Infection. Biochim Biophys Acta. doi: 10.1016/j.bbagen.2008.07.002. Epub 2008 Jul 14.

4. Hassan TH, Badr MA, Karam NA, et al. Impact of iron deficiency anemia on the function of the immune system in children. Medicine (Baltimore). 2016;95(47):e5395. doi:10.1097/MD.0000000000005395

5. Hennigar SR, Mc Clung JP. Nutritional Immunity: Starving Pathogens of Trace Minerals. Am J Lifestyle Med. 2016;10(3):170-173. Published 2016 Feb 4. doi:10.1177/1559827616629117

\section{Сметанин B.H. \\ Эффективность современных технологий инфекционной безопасности в профилактике ИСМП}

Рязанский государственный медицинский университет имени академика И.П. Павлова

(Россия, Рязань)

doi 10.18411/gq-31-07-2021-04

\section{Аннотация}

Инфекции, связанные с оказанием медицинской помощи, представляют важную медицинскую и социальную проблему, так как и в настоящее время занимают одно из первых мест в структуре материнской заболеваемости и смертности. Применение новых диагностических и лечебных технологий позволило существенно уменьшить число тяжелых форм гнойно-воспалительных заболеваний и летальность от них.

Ключевые слова: инфекции, оказание медицинской помощи, заболеваемость, медицинское учреждение, инфекционная безопасность.

\section{Abstract}

Infections associated with the provision of medical care are an important medical and social problem, since they currently occupy one of the first places in the structure of maternal morbidity and mortality. The use of new diagnostic and therapeutic technologies has significantly reduced the number of severe forms of purulent-inflammatory diseases and cases of subsequent mortality.

Keywords: infections, medical care, morbidity, medical institution, infectious safety. 
Заболеваемость инфекциями, связанными с оказанием медицинской помощи (ИСМП) отражает качество медицинской помощи, оказываемой населению, и существенно влияет на уровень экономических затрат. В настоящее время к проблеме ИСМП привлечено внимание медицинских работников различных специальностей: эпидемиологов, гигиенистов, клиницистов, организаторов здравоохранения. Вопросы профилактики ИСМП считаются приоритетным направлением научных исследований [1-4].

Инфекции, связанные с оказанием медицинской помощи представляют важную медицинскую и социальную проблему, так как и в настоящее время занимают одно из первых мест в структуре материнской заболеваемости и смертности. Применение новых диагностических и лечебных технологий позволило существенно уменьшить число тяжелых форм гнойно-воспалительных заболеваний и летальность от них. Несмотря на это, их частота остается высокой, составляя, по данным разных авторов, от 5 до $26 \%$ в мире $[2,5,7]$.

В России точная статистика ИСМП среди акушерских стационаров отсутствует, но, по данным Федерального центра эпидемиологии и гигиены РФ, распространенность ИСМП среди всех стационаров составляет от 1-2\%, что в свою очередь вызывает сомнение.

На протяжении последних 10-15 лет сепсис и септические послеродовые осложнения остаются в числе трех наиболее частых причин материнской смертности в РФ, составляя $26 \%$ в ее структуре. От септических акушерских осложнений во всем мире ежегодно гибнет около 150 тысяч женщин $[3,8,10]$.

За последние годы появились факторы, способствующие повышению заболеваемости ИСМП:

- работа ЛПУ в условиях ограниченного финансирования;

- значительный рост числа резистентных к антибиотикам и дезинфектантам госпитальных штаммов;

- сложность проведения дезинфекции и стерилизации современной дорогостоящей медицинской аппаратуры.

Следует также отметить, что на российском рынке появилось большое количество новых зарубежных и отечественных дезинфицирующих средств, недостаточная и разноречивая информация о которых создает для ЛПО определенные трудности в выборе эффективных препаратов. Кроме того, многочисленные публикации по применению антибиотиков и иммуномодуляторов с целью предупреждения госпитальных инфекций также противоречивы, что не позволяет клиницистам широко включать их в комплекс профилактических мероприятий. Немаловажное значение имеет и отставание разработок нормативной документации федерального уровня, определяющей деятельность ЛПО и профилактику ИСМП на современном этапе $[1,7,9]$.

Остаются актуальными и ранее указанные факторы возникновения ИСМП:

- $\quad$ создание крупных перинатальных центров со своеобразной экологией и интенсивными миграционными процессами;

- наличие в них большого массива источников инфекции;

- нерациональное применение антибиотиков;

- увеличение в популяции групп повышенного риска (недоношенные дети, новорожденные, беременные женщины и родильницы);

- несоответствие нормативам площадей и набора основных и вспомогательных помещений в ЛПО и нарушение в них санитарно-противоэпидемического и санитарно-гигиенического режимов;

- недостаточная компетентность медицинских работников, особенно среднего медицинского персонала, которому отводится основная роль в профилактике ИСМП. 
В родовспомогательных учреждениях регистрируется 34\% ИСМП [2, 5], в структуре которых ведущее место занимают гнойно-септические инфекции - их доля составляет от 60 до $85 \%$.

К потенциально патогенным возбудителям заболеваний относят грамположительные (энтерококки, золотистый и эпидермальный стафилококки, стрептококки группы А и В), грамотрицательные (кишечная палочка, кле- бсиелла, протей, энтеробактерии, синегнойная палочка) аэробные бактерии. Среди анаэробных бактерий встречаются бактероиды, пептококки, пептострептококки. Микробные ассоциации обладают более выраженными патогенными свойствами, чем монокультуры, в связи с наличие синергизма между ними. Это явление носит название «Quorum Sensing», или «чувство кворума». Бактерии способны обмениваться друг с другом сигналами с помощью белковых молекул, и при накоплении определенного количества биомассы бактерий выделение ими факторов патогенности повышается.

За последнее десятилетие изменился видовой спектр возбудителей послеродовых гнойно-септических заболеваний. Наряду с лидирующей этиологической позицией грамотрицательных бактерий, увеличивается значимость грамположительной флоры. Если раньше основным этиологическим фактором по праву считалась кишечная палочка, реже - синегнойная палочка или протей, то сейчас ведущая роль принадлежит энтерококкам (до 65\% всех случаев послеродовых гнойно-септических заболеваний). Это особенно важно знать, потому что энтерококки нечувствительны к цефалоспоринам I и II поколения и аминогликозидам, которые чаще всего используются в акушерских стационарах.

Диагностическим критерием является количество микробных тел более 104 КОЕ/мЛ при бактериологическом исследовании, свидетельствующее о развитии инфекционного процесса.

Следует отметить, что возрастает также число заболеваний, вызванных микроорганизмами, передаваемыми половым путем (хламидии, микоплазмы, вирусы) Следует отметить, что микоплазмы (10\%) и хламидии $(2 \%)$ вызывают вялотекущие формы эндометритов, нередко присоединяясь к первичным возбудителям инфекции.

ИСМП утяжеляют общее состояние пациентов и увеличивают продолжительность пребывания их в стационаре. По данным ВОЗ, летальность в группе лиц с ИСМП значительно (в 10 раз и более) превышает летальность среди аналогичных групп больных без ИСМП.

Ликвидация ИСМП, возникающих в ЛПО, и лечение пораженных ими пациентов требуют значительного бюджетного финансирования. Минимальный экономический ущерб, наносимый ИСМП ежегодно в Российской Федерации, составляет около 5 млрд. руб.

Значимость профилактики ИСМП резко повышается при переходе на принципы социального страхования. Этому способствует и лицензирование медицинских учреждений, поскольку лицензия на право медицинской деятельности возлагает на ЛПО юридическую ответственность за каждый случай внутрибольничного заражения.

Существенным моментом в совершенствовании профилактики ИСМП является создание мотивации в деятельности персонала.

В настоящее время нельзя отказываться от командно-административных и экономических методов управления, которые предполагают материальные поощрения и наказания.

Чрезвычайно важным считаем разработку и совершенствование нормативнометодической документации, регламентирующей проведение гигиенических и противоэпидемических мероприятий в ЛПО, поскольку многие положения существующих документов устарели и требуют скорейшего пересмотра.

Необходимо также повысить действенность санитарно-эпидемиологического надзора за ЛПО. 
Хочется надеяться, что проведенное исследование поможет правильно оценить ситуацию и определить приоритетные меры борьбы с ИСМП в ЛПО различного профиля.

$$
* * *
$$

1. Акимкин В.Г., Музыченко Ф.В. Профилактика внутрибольничных инфекций в лечебнопрофилактических учреждениях Министерства обороны Российской Федерации//Военномедицинский журнал. - 2007. - № 9. - С. 51-56.

2. Брусина Е.Б., Рычагов И.П. Эпидемиологическое значение внутрибольничных инфекций в хирургии и роль различных источников инфекции/Главная медицинская сестра. - 2007. — № 9. - C. 97-102.

3. Постановление Главного государственного санитарного врача РФ от 05.10 .2004 №3 «О состоянии заболеваемости внутрибольничными инфекционными болезнями и мерах по их снижению».

4. Онищенко Г.Г. О состоянии заболеваемости внутрибольничными инфекционными болезнями//Стерилизация и госпитальные инфекции. — 2006. — № 1. - С. 5-7.

5. Письмо Роспотребнадзора от 02.10.2007 №0100/99380732 «О заболеваемости ВБИ в Российской Федерации»//Главная медицинская сестра. — 2007. — № 12. — С. 103-108.

6. Покровский В.И., Семина Н.А. Внутрибольничные инфекции: проблемы и пути решения//Эпидемиология и инфекционные болезни. - 2000. — № 5. - С. 12-14.

7. Покровский В.И., Семина Н.А, Ковалева Е.П. и др. Эпидемиология и профилактика внутрибольничных инфекций в Российской Федерации//Стерилизация и госпитальные инфекции. - 2006. - № 1. - С. 8-11.

8. Семина Н.А, Ковалева Е.П., Фролочкина Т.И. Организация эпидемиологического надзора за внутрибольничными инфекциями в России//В кн. Матер. 8 Съезда эпидемиологов, микробиологов и паразитологов. - М., 2002. - Т. 3. - С. 165-166.

9. Филатов Я.Я, Храпунова И.А., Емелина Ю.Э. и др. О санитарно-техническом состоянии лечебных учреждений г. Москвы и внутрибольничной заболеваемости за 2003 г.//Дезинфекционное дело. 2004. - № 3. - C. 19-24.

10. Филяев В.Н, Мартова О.В, Абросимова Л.М. и др. Динамика уровня и структуры заболеваемости внутрибольничными инфекциями в Астраханской области// Эпидемиология и инфекционные болезни. - 2004. - № 3. - С. 17-18.

\section{Тимербулатов М.В., Шорнина А.С., Ибрагимов Д.Р. \\ Сочетание гернио- и абдоминопластики: основные аспекты и современный взгляд на симультанные операции \\ ФГБОУ ВО Башкирский государственный медиџинский университет Министерства здравоохранения Российской Федеращии}

doi $10.18411 / g q-31-07-2021-05$

(Россия, Уфа)

\section{Аннотация}

Темп современной жизни акцентирует выбор на решении нескольких задач в максимально короткие сроки. Проведение симультанных оперативных вмешательств на передней брюшной стенки позволяет достичь решения комплекса проблем за одну операцию. Выполнение герниопластики с одномоментной коррекцией деформации передней брюшной стенки открывает возможность решить вопросы не только функционального, но и эстетического характера. Индивидуальный подход и знание ведущих хирургических методик, использовавшихся передовыми специалистами, позволяет применять наиболее высокоэффективные и безопасные методы, получить ряд технических преимуществ, снизить процент неудовлетворенности результатами хирургического лечения и минимизировать осложнения. В статье представлен анализ мировой научной литературы, освещающий актуальные аспекты гернио - и абдоминопластики, преимущества и недостатки изолированных и симультанных операций в области передней брюшной стенки, основные хирургические моменты выполняемых оперативных вмешательств. Данная работа направлена на улучшение 